\title{
Nickel Control of Hydrogen Production and Uptake in Anabaena spp. Strains CA and 1F
}

\author{
By ZHANG XIANKONG, ${ }^{1} \dagger$ F. ROBERT TABITA ${ }^{2}$ \\ AND CHASE VAN BAALEN ${ }^{1 *}$ \\ ${ }^{1}$ University of Texas Marine Science Institute, Port Aransas, Texas 78373, USA \\ ${ }^{2}$ Center for Applied Microbiology and Department of Microbiology, University of Texas at \\ Austin, Austin, Texas 78712, USA
}

(Received 30 December 1983)

Net aerobic $\mathrm{H}_{2}$ production and the induction of uptake hydrogenase activity in the nitrogenfixing Anabaena strains $\mathrm{CA}$ and $1 \mathrm{~F}$ were strictly dependent upon the $\mathrm{Ni}^{2+}$ concentration in the growth medium. $\mathrm{Ni}^{2+}$ concentrations as low as $10 \mathrm{nM}$ blocked $\mathrm{H}_{2}$ production and stimulated an uptake hydrogenase activity in whole cells. Two types of uptake hydrogenase activity were seen: a dark aerobic uptake approximately $30 \%$ as active as the $\mathrm{H}_{2}$ production rate, and a lightdependent activity in the presence of DCMU [3-(3,4-dichlorophenyl)-1,1-dimethylurea] at low oxygen concentrations, amounting to about $50 \%$ of the $\mathrm{H}_{2}$ production rate. Together these activities may account for the strong control of net aerobic $\mathrm{H}_{2}$ production by nickel. A significant fraction of the $\mathrm{Ni}^{2+}$-stimulated uptake hydrogenase activity formed during the transition from nickel deficiency to nickel sufficiency was blocked by chloramphenicol. Nickel may be required for activation of an uptake hydrogenase, or for hydrogenase synthesis, or for synthesis of another protein which is involved in $\mathrm{H}_{2}$ uptake.

\section{INTRODUCTION}

High aerobic $\mathrm{H}_{2}$ production has been found in two rapidly growing isolates of marine cyanobacteria, Anabaena spp. strains CA and 1F (Zhang et al., 1983). The net rate of $\mathrm{H}_{2}$ production was some $15 \%$ of the rate of photosynthetic $\mathrm{O}_{2}$ evolution or about $80 \%$ of the rate of acetylene reduction. We have found that aerobic $\mathrm{H}_{2}$ production and uptake hydrogenase activity were regulated by nanomolar levels of $\mathrm{Ni}^{2+}$ added to the growth medium.

\section{METHODS}

Organisms and culture conditions. Anabaena strains CA (ATCC 33047) and 1F were grown on medium ASP-2 (Van Baalen, 1962; Stacey et al., 1977; Gotto et al., 1979) free of added combined nitrogen at $39^{\circ} \mathrm{C}$ with continuous gassing with $1 \% \pm 0 \cdot 1 \%(\mathrm{v} / \mathrm{v}) \mathrm{CO}_{2}$-in-air. With strain $\mathrm{CA}$ the $\mathrm{NaCl}$ content of the medium was $5 \mathrm{~g} \mathrm{l}^{-1}$, with strain $1 \mathrm{~F} 18 \mathrm{~g} \mathrm{l}^{-1}$. The growth bath was illuminated by four fluorescent lamps $(\mathrm{F} 48 \mathrm{~T} 12 / \mathrm{CW} / 1500)$ on each side of the bath, $14 \mathrm{~cm}$ from the lamp centre to the centre of the growth tubes. The intensity, as measured looking through the bath at a light bank, was 450 to $500 \mu \mathrm{E} \mathrm{m}^{-2} \mathrm{~s}^{-1}$ (model 185A Quantum meter, Li-Cor Inc., Lincoln, Nebr., USA). Cell dry weight and growth rates were measured as previously described (Bottomley \& Van Baalen, 1978).

Analytical methods. Amperometric measurement of $\mathrm{H}_{2}$ or $\mathrm{H}_{2}$ and $\mathrm{O}_{2}$ simultaneously was done as previously described (Zhang et al., 1983). The actinic beam was provided by a projector with a DAY-DAK (Sylvania Inc., Winchester, Ky., USA) $500 \mathrm{~W}$ lamp operated at $100 \mathrm{~V}$. The projector beam was screened by a no. 34-01-2 hot mirror (Baird-Atomic Inc., Bedford, Mass., USA). The intensity incident on the electrode chamber was $1200 \mu \mathrm{E} \mathrm{m}^{-2} \mathrm{~s}^{-1}$ and was varied, as desired, using copper screens. Ethylene was detected and measured using a

† Permanent address: Institute of Hydrobiology, Academia Sinica, Wuhan, China.

Abbreviation: DCMU, 3-(3,4-dichlorophenyl)-1,1-dimethlyurea. 
model 464IPC gas chromatograph equipped with an FID detector (Antek Instruments Inc., Houston, Tx., USA) and a $0.33 \times 193 \mathrm{~cm}$ Chromosorb 104 column (Johns-Manville Celite Division, Denver, Colo., USA) with $\mathrm{He}$ as carrier gas at $50^{\circ} \mathrm{C}$.

\section{RESULTS AND DISCUSSION}

The addition of $\mathrm{Ni}^{2+}$ to a nitrogen-fixing culture of Anabaena strains $\mathrm{CA}$ or $1 \mathrm{~F}$ had a profound effect on the net $\mathrm{H}_{2}$ production and on the ability of the cells to take up $\mathrm{H}_{2}$ (Fig. 1). The effect of $\mathrm{Ni}^{2+}$ was in the nanomolar range. This was similar to the growth response obtained with a recently isolated $\mathrm{Ni}^{2+}$-requiring non-nitrogen fixing cyanobacterium, Oscillatoria sp. strain 3NT (Van Baalen \& O'Donnell, 1978). The effect of $\mathrm{Ni}^{2+}$ was not mimicked by $\mathrm{Co}^{2+}$ added at 50 or $100 \mathrm{nM}$. Other possibly important metals such as iron, manganese or perhaps molybdenum are commonly included in a synthetic algal culture medium like ASP-2 (Van Baalen, 1962). There was also little change in the results if the major salts of medium ASP-2 were extracted with 8-hydroxyquinoline before use (Gentry \& Sherrington, 1950). The suppression of aerobic hydrogen production and the stimulation of uptake hydrogenase activity were strictly dependent upon the availability of $\mathrm{Ni}^{2+}$ to the cell. However, neither the growth rate on $\mathrm{N}_{2}$ nor the rate of acetylene reduction were much changed in the presence of added $\mathrm{Ni}^{2+}$ (Table 1 ).

The discrepancy between the high rate of aerobic $\mathrm{H}_{2}$ production and the much lower rates of $\mathrm{H}_{2}$ uptake found for both strains $\mathrm{CA}$ and $1 \mathrm{~F}$ is not easily explained. Uptake hydrogenase

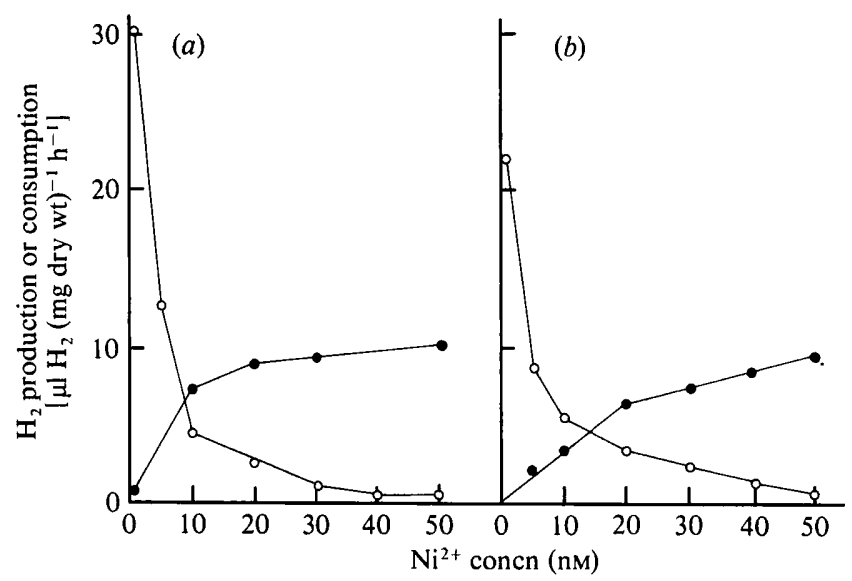

Fig. 1. Effect of $\mathrm{Ni}^{2+}$ on $\mathrm{H}_{2}$ production and consumption of Anabaena strains CA $(a)$ and $1 \mathrm{~F}(b)$. The cultures were grown and measured at $39^{\circ} \mathrm{C}$. The cell densities were $0.16 \mathrm{mg} \mathrm{dry} \mathrm{wt} \mathrm{ml} \mathrm{m}^{-1}$ for both cultures. The cultures were grown for at least five generations with the indicated $\mathrm{Ni}^{2+}$ concentration, then transferred directly from the growth tube to the hydrogen electrode, and bubbled for 3 min with $1 \%(\mathrm{v} / \mathrm{v}) \mathrm{CO}_{2}$-in-air to eliminate the background $\mathrm{H}_{2}$ always present in the cultures. $\mathrm{H}_{2}$ output or uptake was calculated from the slopes of the first $3 \mathrm{~min}$ of the curves. $O$, Rate of hydrogen production in the light; , rate of hydrogen uptake measured in the dark at a saturating hydrogen level, 25 to $35 \mu \mathrm{M}$.

\section{Table 1. Effect of added $\mathrm{Ni}^{2+}$ on growth on $\mathrm{N}_{2}$ and acetylene reduction by Anabaena strains $C A$ and $1 F$}

Two $\mathrm{ml}$ of culture $\left(0.16 \mathrm{mg}\right.$ dry $\left.\mathrm{wt} \mathrm{ml}^{-1}\right)$ was placed in a $7 \mathrm{ml} \mathrm{Vacutainer} \mathrm{tube.} \mathrm{The} \mathrm{gas} \mathrm{phase} \mathrm{was} 1 \%$ $\mathrm{CO}_{2}$-in-air plus $10 \% \mathrm{C}_{2} \mathrm{H}_{2}$. The tubes were incubated in the growth bath for $30 \mathrm{~min}$, and then $0.2 \mathrm{ml}$ of the gas phase was removed and the $\mathrm{C}_{2} \mathrm{H}_{4}$ formed was measured by gas chromatography.

$\begin{array}{cccc}\text { Strain } & \begin{array}{c}\mathrm{Ni}^{2+} \text { concn } \\ (\mathrm{nM})\end{array} & \begin{array}{c}\text { Growth rate } \\ \text { (generation time, h) }\end{array} & \begin{array}{c}\mathrm{C}_{2} \mathrm{H}_{2} \text { red } \\ {[\mu \mathrm{l}(\mathrm{mg} \text { dry wt) }}\end{array} \\ \text { CA } & 0 & 4 \cdot 9 & 42 \\ & 50 & 4 \cdot 1 & 40 \\ 1 \mathrm{~F} & 0 & 4 \cdot 5 & 29 \\ & 50 & 4 \cdot 4 & 25\end{array}$


activity has been noted in nitrogen-fixing cyanobacteria but the question of the number of hydrogenases present and their precise function remains controversial (Tel-Or, 1978; Eisbrenner et al., 1981). In addition to dark $\mathrm{H}_{2}$ uptake, a light-driven uptake was discernible in nickel-sufficient cells in the presence of DCMU at a low oxygen concentration (Fig. 2). Interestingly, the $\mathrm{H}_{2}$ uptake rate was $17 \mu \mathrm{H}_{2}$ (mg dry wt) $)^{-1} \mathrm{~h}^{-1}$, nearly twice the dark aerobic rate. This suggests that there may be two sinks for $\mathrm{H}_{2}$, one to oxygen and the other through photosystem I. If these are independent and, therefore additive, they could account for the net aerobic $\mathrm{H}_{2}$ production falling to nearly zero in the presence of $\mathrm{Ni}^{2+}$.

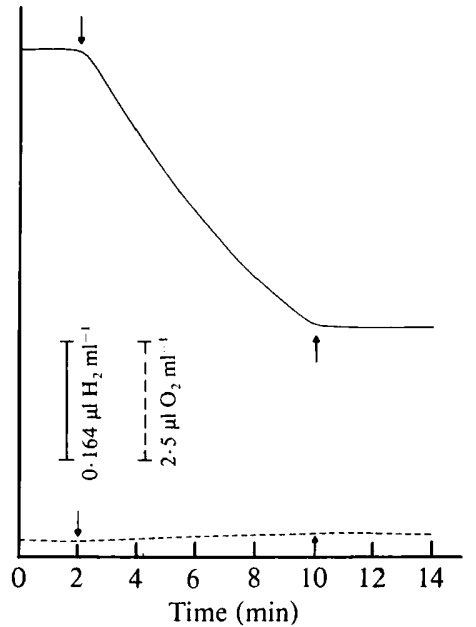

Fig. 2. Tracings, reduced in scale, of hydrogen uptake (-), and oxygen output (----) of Anabaena strain CA in the presence of DCMU. A culture grown in the presence of $50 \mathrm{nM}^{-\mathrm{Ni}^{2+}}$ was transferred directly from the growth bath to the electrode chamber and gassed for $5 \mathrm{~min}$ with $1 \% \mathrm{CO}_{2}-\mathrm{in}-\mathrm{N}_{2}$ in the dark. The cell density was $0.2 \mathrm{mg}$ dry wt $\mathrm{ml}^{-1}$. Arrows down indicate light on, arrows up light off. DCMU was added as an ethanolic solution $(1 \mu \mathrm{l})$ to give a final concentration of $2 \times 10^{-5} \mathrm{M}$ at zero time.

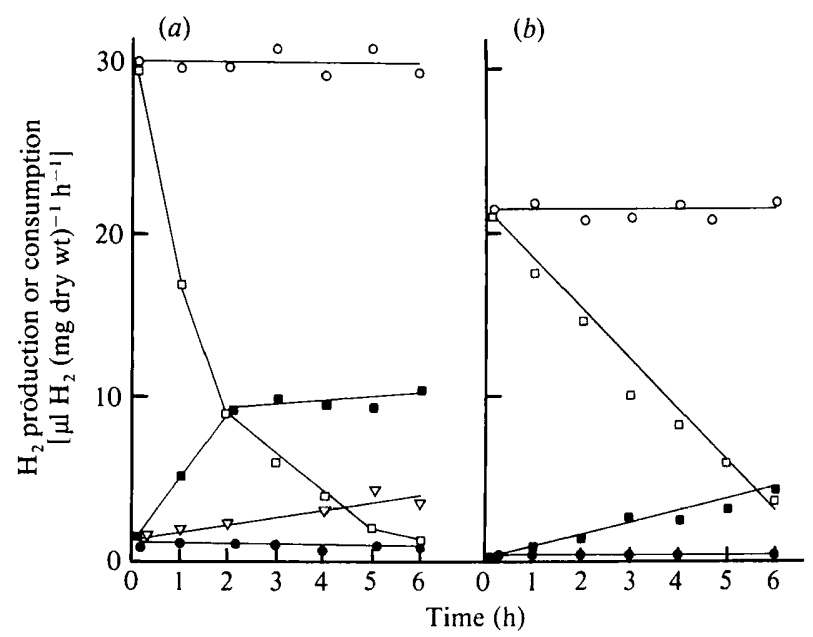

Fig. 3. Time course of decay in $\mathrm{H}_{2}$ production and the increase in uptake hydrogenase activity after addition of $\mathrm{Ni}^{2+}$ to Anabaena cultures. $\mathrm{Ni}^{2+}, 50 \mathrm{nM}$, was added to a culture of strain $\mathrm{CA}(a)$ or strain $1 \mathrm{~F}$ (b) at zero time and the cultures were immediately returned to the growth bath. At the indicated times samples of the culture were transferred to the $\mathrm{H}_{2}$ electrode and the rate of $\mathrm{H}_{2}$ production was determined as described for Fig. $1 . \bigcirc, \mathrm{H}_{2}$ production, no added $\mathrm{Ni}^{2+} ; O, \mathrm{H}_{2}$ uptake, no added $\mathrm{Ni}^{2+}$; $\square, \mathrm{H}_{2}$ production with $\mathrm{Ni}^{2+}$ present; $\square, \mathrm{H}_{2}$ uptake with $\mathrm{Ni}^{2+}$ present; $\nabla, \mathrm{H}_{2}$ uptake with $\mathrm{Ni}^{2+}$ and chloramphenicol $\left(20 \mu \mathrm{g} \mathrm{m}^{-1}\right)$ present. 
Nickel has been found in several hydrogenases (Graf \& Thauer, 1981 ; Friedrich et al., 1982) and a nickel-dependent uptake hydrogenase can explain the dramatic decay in net aerobic $\mathrm{H}_{2}$ production (Fig. 1). Similar observations on nickel controlling $\mathrm{H}_{2}$ uptake and aerobic $\mathrm{H}_{2}$ production have been found in Anabaena cylindrica (Daday \& Smith, 1983). However, in addition to hydrogenase, nickel is known to be a constituent of jack-bean urease (Dixon et al., 1976); of carbon monoxide dehydrogenase (Diekert et al., 1979) and of factor 430, a nickel tetrapyrrole of unknown structure, in Methanobacterium thermoautotrophicum (Diekert et al., 1980; Ellefson et al., 1982). A second function of $\mathrm{Ni}^{2+}$ in controlling $\mathrm{H}_{2}$ production is, therefore, not ruled out at this time.

The time course of decay of net $\mathrm{H}_{2}$ production and the stimulation of uptake hydrogenase activity after the addition of $\mathrm{Ni}^{2+}$ to cultures of strains $\mathrm{CA}$ or $1 \mathrm{~F}$ was in terms of hours, and chloramphenicol blocked a significant fraction of the $\mathrm{Ni}^{2+}$-induced uptake hydrogenase activity formed in strain CA (Fig. 3). The availability of nickel to a cell may control the synthesis of uptake hydrogenase or the synthesis of another protein which activates uptake hydrogenase activity. We are presently examining this point and whether the increased uptake hydrogenase activity will reside in isolated, active heterocysts.

This work was supported in part by grant 83-CRCR-1-1286 from the US Department of Agriculture. We thank Rita O'Donnell for excellent technical assistance.

The University of Texas Marine Science Institute Contribution no. 607.

\section{REFERENCES}

Bottomley, P. J. \& Van BaAlen, C. (1978). Dark hexose metabolism by photoautrophically grown cells of the blue-green alga (cyanobacterium) Nostoc sp. strain MAC. Journal of Bacteriology 135, 888894.

DaDAY, A. \& Smith, G. D. (1983). The effect of nickel on the hydrogen metabolism of the cyanobacterium Anabaena cylindrica. FEMS Microbiology Letters 20 , 327-330.

Diekert, G. B., Graf, E.-G. \& Thauer, R. (1979). Nickel requirement for carbon monoxide dehydrogenase formation in Clostridium pasteurianum. Archives of Microbiology 122, 117-120.

Diekert, G., Weber, B. \& Thauer, R. (1980). Nickel dependence of Factor 430 content in Methanobacterium thermoautotrophicum. Archives of Microbiology 127, 273-278.

Dixon, N. E., Gazzola, C., Blakeley, R. L. \& ZERNER, B. (1976). Metal ions in enzymes using ammonia or amides. Science 191, 1144-1150.

Eisbrenner, G., Roos, P. \& Bothe, H. (1981). The number of hydrogenases in cyanobacteria. Journal of General Microbiology 125, 383-390.

Ellefson, W. L., WhitMan, W. B. \& Wolfe, R. S. (1982). Nickel-containing factor $F_{430}$ : chromophore of the methylreductase of Methanobacterium. Proceedings of the National Academy of Sciences of the United States of America 79, 3707-3710.

Friedrich, C. G., SCHNeIder, K. \& Friedrich, B. (1982). Nickel in the catalytically active hydrogenase of Alcaligenes eutrophus. Journal of Bacteriology 152 , 42-48.

Gentry, C. H. R. \& SherRington, L. G. (1950). Extraction and photometric estimation of some metals with 8-hydroxyquinoline. Analyst 75, 1721.

Gotto, J. W., Tabita, F. R. \& Van BaAlen, C. (1979). Isolation and characterization of rapidly-growing marine, nitrogen-fixing strains of blue-green algae. Archives of Microbiology 121, 155-159.

Graf, E.-G. \& THAUER, R. (1981). Hydrogenase from Methanobacterium thermoautotrophicum, a nickel containing enzyme. FEBS Letters 136, 165-169.

Stacey, G., Van BaAlen, C. \& Tabita, F. R. (1977). Isolation and characterization of a marine Anabaena sp. capable of rapid growth on molecular nitrogen. Archives of Microbiology 114, 197-201.

Tel-OR, E., LuiJk, L. J. \& PACKer, L. (1978). Hydrogenases in $\mathrm{N}_{2}$-fixing cyanobacteria. Archives of Biochemistry and Biophysics 185, 185-194.

VAN BAALEN, C. (1962). Studies on marine blue-green algae. Botanica Marina 4, 129-139.

VAN BAALEN, C. \& O'DONNELL, R. (1978). Isolation of a nickel-dependent blue-green alga. Journal of General Microbiology 105, 351-353.

Zhang, X., Haskell, J. B., Tabita, F. R. \& Van BAALEN, C. (1983). Aerobic hydrogen production by the heterocystous cyanobacteria, Anabaena spp. strains CA and $1 \mathrm{~F}$. Journal of Bacteriology 156, 1118 1122. 